\title{
Pengaruh Teknik Baby Solus Per Aqua (Baby Spa) Terhadap Berat dan Panjang Badan Bayi 3-6 Bulan
}

\author{
Ade Kurniawati ${ }^{1}$, Dewi Nurdianti ${ }^{2}$, Ratni $\mathbf{N}^{3}$ \\ 1, 2, 3 Prodi D3 Kebidanan Universitas Muhammadiyah Tasikmalaya, \\ Email : adekur@umtas.ac.id ;, dewi.nurdianti@umtas.ac.id; , ratni@umtas.ac.id
}

\begin{abstract}
ABSTRAK
Latar Belakang : Masa bayi merupakan masa dimana pertumbuhan dan perkembangan terjadi secara cepat pada anak. Salah satu cara untuk menstimulasi pertumbuhan dan perkembangan pada anak yaitu dengan menggunakan teknik baby solus per aqua (SPA) yang dilakukan dengan tahapan pemanasan, berenang dan pemijatan.

Tujuan : penelitian ini adalah untuk mengetahui pengaruh pemberian baby spa terhadap peningkatan berat badan dan panjang badan pada bayi 3-6 bulan.

Metode : Penelitian ini merupakan penelitian quasi eksperimental design dengan rancangan penelitian one group pre-posttest. Teknik sampling yang digunakan adalah purposive sampling sejumlah 20 bayi dengan usia 3-6 bulan di Klinik Baby SPA Madre dan Marwah. Baby Spa dilakukan 1x seminggu sebanyak 4x, analisa data menggunakan paired t-test.

Hasil : penelitian diketahui bahwa terdapat pengaruh baby spa terhadap berat badan dan terdapat pengaruh baby spa terhadap panjang badan. Sebagai rekomendasi pada ibu bayi balita untuk rutin melakukan baby spa, sehingga pertumbuhan bayi akan lebih maksimal.
\end{abstract}

Kata Kunci : bayi, baby SPA, pertumbuhan fisik

\begin{abstract}
Background: Infancy is a period where growth and development occur rapidly in children. One way to stimulate growth and development in children is by using the baby solus per aqua (SPA) technique which is done by heating, swimming and massage.

Purpose: This study was to determine the effect of giving a baby spa on the increase in body weight and body length in infants 3-6 months.

Methods: This study is a quasi-experimental study design with a one group pre-posttest research design. The sampling technique used was purposive sampling of 20 infants aged 3-6 months at Madre and Marwah Baby SPA Clinic. Baby Spa was carried out once a week for 4 times, data analysis used a paired t-test.

Results: The study found that there was an effect of baby spa on body weight and there was an effect of baby spa on body length. As a recommendation for mothers of babies under five to regularly do a baby spa, so that the baby's growth will be maximized.
\end{abstract}

Keywords: baby, baby SPA, physical growth

PENDAHULUAN

Seribu hari pertama kehidupan merupakan saat terpenting dalam hidup seseorang. Sejak saat perkembangan janin di dalam kandungan, hingga ulang tahun yang kedua menentukan kesehatan dan kecerdasan seseorang. Masa bayi merupakan masa dimana pertumbuhan dan perkembangan terjadi secara cepat pada anak (1). Bayi merupakan manusia yang baru lahir sampai umur bayi kurang dari 12 bulan. Masa bayi adalah masa yang bergantung pada orang dewasa. Banyak kegiatan psikologis yang terjadinya sebagai permulaan seperti bahasa, pemikiran simbolis, koordinasi sensorimotor, dan belajar sosial (2) 
Periode ini merupakan periode kritis yang terjadi sekali dalam kehidupan anak, gangguan yang dialami anak dalam periode ini berdampak terhadap perkembangan fisik dan kognisi anak. Prevalensi gangguan tumbuh kembang di Indonesia mencapai $12,8 \%$ sampai dengan $16 \%$. Program pemerintah yang dilakukan untuk menanggulangi permasalahan gangguan tumbuh kembang adalah dengan stimulasi, deteksi, intervensi dini tumbuh kembang. Salah satu upaya untuk mencegah keterlambatan pertumbuhan dan perkembangan anak yaitu dengan cara adanya stimulasi pertumbuhan dan perkembangan anak serta terjangkaunya pelayanan pertumbuhan dan perkembangan anak yang dapat mencegah terjadinya penyimpangan ${ }^{(3)}$.

Salah satu cara untuk menstimulasi pertumbuhan dan perkembangan pada anak yaitu dengan menggunakan teknik baby solus per aqua (SPA). Baby SPA merupakan upaya tradisional yang menggunakan pendekatan holistik, melalui perawatan menyeluruh dengan menggunakan metode kombinasi antara hydrotherapy (terapi air) dan massage (pijat) yang dilakukan secara terpadu untuk menyeimbangkan tubuh, pikiran serta perasaan ${ }^{(4)}$. Penelitian ini bertujuan untuk mengetahui pengaruh baby SPA terhadap berat dan panjang badan bayi usia 3-6 bulan di klinik baby SPA kota Tasikmalaya.

\section{METODE}

Penelitian ini merupakan penelitian quasi eksperimental design dengan rancangan penelitian one group pre-posttest. Populasi pada penelitian ini adalah seluruh bayi yang datang ke klinik Madre Baby SPA dan Mom's Baby SPA pada periode bulan Juli sampai September 2020. Teknik sampling yang digunakan adalah purposive sampling yaitu pemilihan subjek dengan kriteria usia 3-6 bulan, bayi sehat, datang ke klinik baby spa pada saat penelitian berlangsung Penentuan jumlah sampel berdasarkan jumlah sampel minimal yaitu 30 orang. Pengukuran berat badan menggunakan timbangan yang telah dikalibrasi, sedangkan pengukuran panjang badan dengan menggunakan meja pengukur yang telah terstandar. Berat badan dan panjang badan dipantau dengan menggunakan lembar KMS pada 1 bulan setelah diberikan $4 x$ baby SPA. Perawatan baby spa dilakukan dalam 2 tahap yaitu berenang selama 5-10 menit dan pijat selama 20 menit. Perawatan baby spa diulang setiap 1 minggu $1 \mathrm{x}$. Analisis data untuk uji hipotesis menggunakan paired ttest.

\section{HASIL}

Penelitian ini dilakukan di klinik Madre Baby SPA dan Mom's Baby SPA. Subjek yang direncanakan sebanyak 30 bayi namun karena pandemic Covid-19 dengan diberlakukannya PSBB maka sampel yang terkumpul hanya 20 bayi. 
Tabel 1. Karakteristik Bayi

\begin{tabular}{ccc}
\hline & f & $\%$ \\
\hline Usia : 3 & 9 & 45 \\
4 & 5 & 25 \\
5 & 2 & 10 \\
6 & 4 & 20 \\
\hline Jenis Kelamin : Laki-laki & 9 & 45 \\
Perempuan & 11 & 55 \\
\hline
\end{tabular}

Berdasar atas tabel 1 diketahui bahwa usia bayi paling banyak adalah 3 bulan (45\%) dan jenis kelamin lebih banyak perempuan $(55 \%)$

Tabel 2. Berat Badan dan Panjang Badan Bayi Sebelum dan Sesudah Baby SPA

\begin{tabular}{lcccc}
\hline & $\mathrm{n}$ & mean & std.deviasi & $\mathrm{p}(\mathrm{CI} 95 \%)$ \\
\hline Berat Badan & & & & \\
Pre Test & 20 & 6165 & 1060,9 & $0,001(-662,834-507,166)$ \\
$\quad$ Post Test & 20 & 6750 & 1047 & \\
\hline Panjang Badan & & & & \\
Pre Test & 20 & 60,9 & 3,3 & $0,001(-1,902-1,098)$ \\
Post Test & 20 & 62,4 & 3,1 & \\
\hline
\end{tabular}

Dari tabel 2 diperoleh nilai perbedaan rata-rata berat badan bayi sebelum intervensi setelah intervensi ratarata berat badan bayi sebesar $-585 \mathrm{gr}$, berdasarkan hasil analisis dengan paired ttest terdapat pengaruh baby spa terhadap berat badan. Perbedaan Rata-rata panjang badan bayi sebelum intervensi dan setelah intervensi adalah $-1,5 \mathrm{~cm}$, berdasarkan hasil analisis dengan paired t-test terdapat pengaruh baby spa dan panjang badan bayi.

\section{PEMBAHASAN}

Baby Solus Per Aqua (Baby SPA) dapat diartikan sebagai rangkaian kegiatan yang diberikan kepada bayi dengan tujuan untuk relaksasi pada bayi. Melalui kegiatan spa, bayi dapat merasakan relaksasi karena ketika lahir bayi harus beradaptasi dengan perubahan lingkungan. Bayi yang berada selama sembilan bulan terlindung di perut ibu yang gelap dan hangat, sedangkan ketika lahir harus menghadapi suhu dingin.
Selain itu, relaksasi pada bayi bukan hanya untuk menghilangkan stress, tetapi merupakan hal yang penting bagi proses tumbuh kembang anak ${ }^{(6)}$.

Penelitian ini sesuai dengan penelitian Firdaus bahwa selama proses perawatan baby spa sebaiknya ditangani oleh terapis yang berpengalaman, bahanbahan yang digunakan tidak mengakibatkan alergi pada bayi (bahan pilihan) serta pengaturan dekorasi ruangan juga harus diperhatikan, beragam mainan untuk bayi dengan pertimbangan yang cermat dan warna-warna yang cerah untuk merangsang indera visual bayi ${ }^{(7)}$.

Frekuensi spa yang dilakukan pada bayi akan lebih efektif jika frekuensinya sesuai dengan anjuran. Dalam penelitian ini responden melakukan sesuai dengan anjuran yaitu 4 kali dalam sebulan(8). Gerakan pemijatan yang dilakukan untuk bayi 3 bulan - 3 tahun dengan tekanan dan 
waktu yang makin meningkat dan total waktu pemijatan disarankan sekitar 15 menit(9). Durasi waktu berenang selama 15 menit. Apabila bayi merasa tidak nyaman sebelum 15 menit, angkat bayi dan segerakan untuk dimandikan di bak mandi terpisah

Proses baby spa yang dilakukan dengan tahapan pemanasan, berenang dan pemijatan. Bayi yang diterapi dengan spa akan terlihat lebih segar, sehat, dan bersemangat, meningkatkan gerakan motorik anak, meningkatkan jumlah makanan yang diserap tubuh (termasuk ASI-air susu ibu), meningkatkan imunitas anak. spa juga bermanfaat untuk mendeteksi kelainan tumbuh kembang pada bayi dan anak secara dini ${ }^{(5)}$.

Setelah bayi melakukan treatment baby spa, nafsu makan bayi akan meningkat dan pola tidur bayi akan menjadi lebih baik sehingga bayi mengalami peningkatan berat badan yang lebih baik dari baby massage yang bersifat relaksasi. Dengan bayi bermain air, otot-otot bayi akan berkembang dengan sangat baik, persendian tubuh akan bekerja secara optimal, pertumbuhan badan meningkat dan tubuh pun menjadi lebih lentur atau dengan kata lain gerakan di dalam air semua anggota tubuh bayi akan terlatih, karena seluruh anggota tubuh digerakkan mulai dari kaki, tangan, hingga kepala walaupun gerakannya belum begitu sempurna (10).

Berdasar atas tabel 1 dapat diketahui bahwa rata-rata berat badan bayi sebelum dilakukan baby spa adalah 6165gr, sedangkan setelah baby spa rata-rata berat badan bayi sebesar 6750 gr dengan rata-rata kenaikan berat badan bayi sebesar 585 gram.

Penelitian ini sesuai dengan penelitian yang dilakukan oleh Puteri bahwa ada pengaruh pemberian teknik baby spa terhadap kenaikan berat badan. Perawatan baby spa salah satunya adalah pemijatan, hal ini sangat berpengaruh pada kenaikan berat badan bayi. Banyak penelitian mengungkapkan bahwa bayi yang diberikan perawatan baby spa meningkatkan berat badan sekitar $47 \%$ per hari (10)(12).

Rata-rata panjang badan bayi sebelum baby spa adalah $60,9 \mathrm{~cm}$ sedangkan rata-rata panjang badan setelah baby spa adalah $62,4 \mathrm{~cm}$, dengan rata-rata kenaikan sebesar $1,5 \mathrm{~cm}$.

Penelitian ini selaras dengan penelitian yang dilakukan oleh Asih dan Mirah yang mengungkapkan bahwa terdapat perbedaan panjang badan yang signifikan antara bayi yang tidak diberi pijat bayi dengan yang diberi pijat bayi secara teratur. ${ }^{(13)}$

Hal ini sejalan dengan hasil penelitian sebelumnya didapatkan pemberian ataupun perlakuan pijatan dan latihan gerak dapat meningkatkan perkembangan fisik dan kecerdasan bayi mulai dari bayi lahir hingga dengan bayi usia 6 bulan terjadinya peningkatan tinggi badan yang signifikan pada bayi yang diberikan terapi sentuhan berupa pijat bayi dibandingkan dengan bayi yang tidak mendapatkan perlakuan pijatan (14)

Pemijatan tubuh disertai aktivitas berenang akan melatih otot dan tulang bayi yang akan meningkatkan kepadatan tulang dan mempercepat pertumbuhan tulang, karena pemijatan tubuh dapat memicu 
pertumbuhan tulang lebih cepat. Selain itu, pada saat berenang dalam air efek gravitasi sangat rendah sehingga memungkinkan bayi bergerak lebih banyak dan semua otot dapat bekerja optimal (15).

Pertumbuhan fisik dipengaruhi oleh faktor internal dan eksternal. Selain pemberian stimulasi dengan baby spa, terdapat faktor lain yang juga ikut berpengaruh terhadap proses pertumbuhan bayi, misalnya faktor genetik yang merupakan modal dasar dan mempunyai peran utama dalam mencapai hasil akhir proses tumbuh kembang, dan faktor prenatal yang mempengaruhi anak sebelum lahir dan yang terakhir faktor postnatal yang mempengaruhi anak setelah lahir ${ }^{(16)}$.

\section{KESIMPULAN}

Terdapat pengaruh baby SPA terhadap berat badan dan panjang badan bayi usia 3-6 bulan di klinik baby SPA Kota Tasikmalaya.

\section{SARAN}

Diharapkan pada ibu bayi balita untuk rutin melakukan baby spa, sehingga pertumbuhan bayi akan lebih maksimal, bagi peneliti selanjutnya untuk meneliti faktor-faktor yang mendukung pemberian baby spa dalam peningkatan pertumbuhan bayi

\section{UCAPAN TERIMA KASIH}

Terima kasih peneliti ucapkan pada:

1. KEMENRISTEK DIKTI yang telah mendanai penelitian

2. Ketua LPPM Universitas Muhammadiyah Tasikmalaya

3. Ketua Prodi D3 Kebidanan Universitas Muhammadiyah Tasikmalaya

4. Madre Baby SPA dan Marwah Baby Care

\section{DAFTAR PUSTAKA}

1. Ambarwati F., Nasution N. Asuhan Keperawatan Bayi dan Balita. 1st ed. Yogyakarta: Cakrawala Ilmu; 2015.

2. Marmi, Rahardjo. Asuhan Neonatus, Bayi, Balita, dan Anak Prasekolah. 1st ed. Yogyakarta: Pustaka Pelajar; 2012.

3. Maritalia D. Analisis pelaksanaan program stimulasi, deteksi dan intervensi dini tumbuh kembang (SDIDTK) balita dan anak pra sekolah di Puskesmas Kota Semarang tahun 2009 [Internet]. 2009. Available from: http://eprints.undip.ac.id/19681/

4. Rachmawati W. Pengaruh Baby Spa terhadap Peningkatan Perkembangan Motorik Kasar pada Bayi di My Baby Spa Surabaya. J Kesehat Olahraga. 2016;4(3).

5. Yahya N. Spa Bayi dan Anak. Solo: Metagraf; 2011.

6. Ekasari WU, Arum RM. Hubungan Frekuensi Kunjungan Baby SPA dengan Kenaikan Berat Badan Bayi Usia 3-12 Bulan Di Klinik Luqi Medika. 2018;001:16-22.

7. Firdaus N. Pengaruh Baby Spa Terhadap Perkembangan Bayi Usia 3-6 Bulan di Puskesmas Socah Bangkalan. J Ilm Ilmu Kebidanan Kandung [Internet]. 2019;11(1):19-25. Available from: https://stikes-nhm.e-journal.id/JOB/article/view/25

8. Prastiani DB, Setyaningrum I. Hubungan Frekuensi Baby Spa Dengan Pertumbuhan Fisik Bayi usia 6-12 Bulan. J Keperawatan Respati Yogyakarta [Internet]. 2017;4(1):80-4. Available from: http://nursingjurnal.respati.ac.id/index.php/JKRY/article/view/87

9. Roesli U. Pedoman Pijat Bayi. Jakarta: Trubus Agriwidya; 2014.

10. Jayatmi, I., \& Fatimah J. Pertumbuhan Optimal dengan Pijat dan Spa Bayi. J Pengabdi Masy Indones Maju [Internet]. 2020;1(2):54-61. Available from: http://journals.stikim.ac.id/ index.php/ JLS1/article/view/663

11. Puteri VTA, Taufik, S., \& Nurul M. Pengaruh Tekhnik Baby Spa terhadap Perkembangan Motorik 
dan Kenaikan Berat Badan Bayi. Mahakam Midwifery Journal(MMJ). 2019;4(1):324-9.

12. Faradita Wahyuni RPD. Hubungan Lama Mengikuti Baby Spa Dengan Kenaikan Berat Badan Bayi Usia 0-6 Bulan Di Yayasan Ibu Kompleks Medan Permai Kota Medan. J Kebidanan Kestra [Internet]. 2018;2(2): 1-9. Available from: https://ejournal. medistra.ac.id/ index.php/ JKK/ article/view/343

13. Asih Y, Mirah WS IGA. Optimalisasi Pertumbuhan Bayi dengan Baby Massage and Spa. J Kesehat. 2019;10(2):276.

14. Hartaty A D, Fauziah. Pengaruh Pijat Bayi terhadap kenaikan Berat Badan dan Panjang Badan pada Bayi. In: Proceeding International Midwifery Scientific Conference 2018 [Internet]. Jakarta: Indonesian Midwives Association (IBI/IMA); 2018. p. 212-5. Available from: http://digilib.poltekkesdepkes-sby.ac.id/public/POLTEKKESSB Y-Proceeding-4106-Prosiding 20PII202018_compressed.pdf\#page=229

15. Margiana W, Muflihah IS. Pengaruh Baby Spa Terhadap Kenaikan Berat Badan Bayi. 2018;10:2931.

16. Soetjiningsih. Tumbuh Kembang Anak. 2nd ed. Jakarta: EGC; 2014. 